\title{
Scholastic Grammar in College English Teaching
}

\author{
Yanghua Peng ${ }^{1}$ \\ ${ }^{1}$ School of Foreign Languages, Chengdu College of Arts and Sciences, Chengdu City, Sichuan Province, China \\ Correspondence: Yanghua Peng, 888 Minxing Road, Chenghua District Chengdu City, Sichuan Province, China. \\ E-mail: pengls@126.com
}

$\begin{aligned} & \text { Received: February 24, } 2017 \quad \text { Accepted: March 13, } 2017 \quad \text { Online Published: July 15, } 2017 \\ & \text { doi:10.5539/ijel.v7n4p191 }\end{aligned}$ URL: http://doi.org/10.5539/ijel.v7n4p191

\begin{abstract}
The research of grammar has been received much concern at home and abroad and the instruction of grammar is a focus and difficulty in English language teaching. The role of scholastic grammar has been paid little attention to for a long time. Some linguists and teachers believe that the traditional or school grammar should be the key in the classroom instruction, but others argue that scholastic grammar is a vital part in language itself. Based on the theories of second language learning and the viewpoints of Otto. Jespersen and H. Poutsma about scholastic grammar, this article conducts a research in colleges and analyzes the stylistic effect of attributive post-position from scholastic grammar perspective and finds that it is necessary to reconsider the important role of scholastic grammar in college English teaching. The paper ends with a conclusion about some implications of the present research for college English language teaching in China.
\end{abstract}

Keywords: college English teaching, scholastic grammar, traditional grammar

\section{Introduction}

\subsection{Introduce the Problem}

It is traditionally considered that grammar is school grammar, which prescribes rules of "correctness". It is roughly referred to the general approach thus traditionally formed to the study of language over the years. There is some absolute standard of correctness concerning language use which linguists or school teachers should view as their duty to maintain. There have been, therefore, theorists and teachers pointing out that school grammar is fundamental in English language teaching. However, the exclusion of attention to scholastic grammar is never a necessary part of foreign language teaching. Then, scholastic grammar differs from traditional grammar in that it is human approach to grammar. Not only does it explain what the usage is and most important is that why it will be used like that and the nice effect of such usage. In other words, it will make learner quite clear about what, why and how. As everybody can see, there is much more to do in learning a language than just acquiring the grammatical rules as the traditional grammarians do in the past.

\subsection{Explore Importance of the Problem}

It is undoubted that the important role of grammar can't be neglected in English language teaching. Without learning the grammar of a language, it is hard, and though not impossible, to acquire the ability to produce grammatically acceptable utterances. This is especially applicable to second language learners, most of whom have to acquire the second language in classroom, in the organized textbook. The research of grammar has been received much concern at home and abroad and grammar instruction is becoming a hot potato. College English teaching and learning becomes more and more important in China today. It is generally believed that there are three major systems of grammar in theory: scholastic grammar, traditional grammar and modern grammar probably. This paper will be solely concerned with the first two in college English teaching.

\subsection{Describe Relevant Scholarship}

As early as 1960s, Chomsky put forward: "A grammar can be regarded as a theory of a language; it is descriptively adequate to the extent that it correctly describes the intrinsic competence of idealized native speaker (Chomsky, 1966)." He went on to explain that a grammar describes and attempts to account for the ability of the speaker to understand an arbitrary sentence and produce an appropriate sentence on a given occasion (Chomsky, 1967). Harmer claims that the grasp of grammar is essential for any language user (Harmer, 1983). Alexander even argues that the ultimate source of accuracy in any language is grammar. "Grammar plays 
a very supportive role and we can say that it is a shortcut to language acquisition (Alexander, 2000)." Furthermore, from Otto Jesperson's point of view, as far as grammar is concerned, it is the art technique of writing, which is a real reflection of rational thinking, noble character and vital soul of a nation. There is cultural wisdom of a nation which underlies grammar.

\section{Methods}

Selecting 10 young English teachers at university for an in-depth interview, the author intended to get to know about the real instruction of grammar in college English teaching.

\subsection{Subject}

There are 10 subjects in this research. The subjects are young college English teachers under 40 working in ten different colleges varying from key university to vocational college (Table 1). Among them, some are vice professor, some are lecturer and some are teaching assistant.

Table 1. Background of participants

\begin{tabular}{cllll}
\hline Number & Degree & Title & Years at college & Working unit \\
\hline 1 & Post doctorate & vice professor & 9 & National Normal U \\
2 & Post doctorate & vice professor & 11 & Provincial Multiversity \\
3 & Post doctorate & vice professor & 2 & Foreign Language Studies U \\
4 & Doctorate & lecturer & 13 & Provincial Normal U \\
5 & Doctorate & lecturer & 7 & National U of Technology \\
6 & Doctor & lecturer & 12 & U for Nationalities \\
7 & Doctor & lecturer & 18 & Normal U \\
8 & Master & teaching assistant & 18 & Multiversity \\
9 & Master & teaching assistant & 3 & Foreign Language Studies U \\
Note. $\mathrm{U}=$ university. & Master & teaching assistant & 2 & U of Technology \\
\end{tabular}

\subsection{Relationship of Interviewer and Interviewee}

The interviewer is the author of the article. The interviewees are the author's friends or former classmates and they trust and understand each other. The interviewer is familiar with qualitative study and some communication skills. The participants have been informed of the research purpose and their names omission in the article, so the feedback of the interview in the research is reliable to some extent.

\subsection{Data Collection}

The interviewer has prepared an outline of the interview, in which includes background information of the interviewees, professional trainings, and professional teaching plans and so on. Actually, the interviewees feel quite free and comfortable without any stress because they just like chats with their friends. What they chatted has been adjusted and they are permitted to ask any questions to ensure the authenticity and reliability.

The interview goes one by one, and each one last from 40 to 100 minutes. Totally the interviewing hour is 9.5 hours. With the permission of the interviewees, the interviewer recording what they said in the overall process. And then their talks has been transformed into166208 text words.

\subsection{Data Analyses}

In the research, the grounded theory methods (GTM), developed by Barney Glaser and Anselm Strauss, are applied to deal with the codes. Firstly, the data is pretreated while interviewing is proceeding. Number the interviewer for the sake of the data management. Key words and codes in GTM are categorized and analyzed. Try to find the key words in the data.

\section{Result}

Based on the analyses of the research, the findings can be categorized into three types. Firstly, scholastic grammar is neglected totally and traditional grammar is dominated in English language teaching; secondly, scholastic grammar is mentioned sometimes but traditional grammar got more preference; thirdly, scholastic grammar is dominated and traditional grammar is despised. 

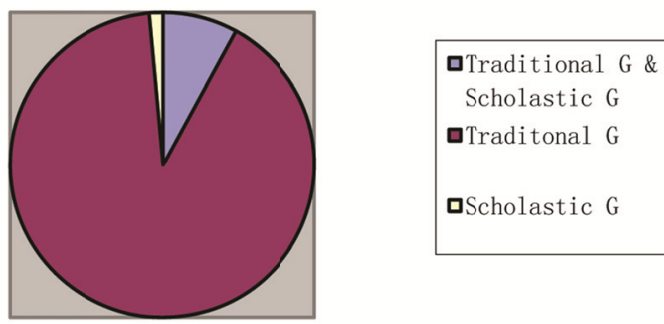

Figure 1. Proportion of the scholastic grammar instruction

Note. $\mathrm{G}=$ Grammar.

Just as mentioned previously, the traditional grammar is not descriptive but prescriptive which aims to lay down rules for "correct and standard" behavior in using language, i.e., to tell people what they should say and what they should not say without giving any reason. Or to put it another way, the teaching of grammar to some extent is only to be found for grammar's own sake. What's worse, some English teachers are not quite clear about grammar itself because they are taught grammar in way of reciting the grammatical rules. Mostly, they employ the grammar-translation methods. In this method, every unit is devised around the focal point of grammar. The main activities in the classroom are oral translation of the texts into the target language. Grammatical rules are discovered through repeated practice of translation Grammar-translation method in traditional grammar emphasizes too much the mastering of the structure of the language as an object of study, without any thought about the language. The result of this method in the past was that students who had spent years studying English could possibly understand quite difficult literary texts, but they probably were incapable of ordering a cup of tea. It seems that the learners have a lot of knowledge but actually this is so superficial that it is far from what learners want. Language is never something dead. It is not sufficient for students to remember the grammatical rules or even produce grammatical sentences; they must know when, why and how to use them.

\section{Discussion}

Language learners don't acquire language in the same way as they acquire their mother tongue unless they are under exceptional circumstances. Their English study is subject to enormous constraints, such as the different tradition, different religion and lifestyle etc. In short, the cross-cultural gap is responsible for the problem. In order to know the English language well, learners are asked to do lots of exercises related to traditional grammar. To their surprise, learners find, on not rare occasions, derivations from the regular rules. More interesting is that some English teachers would distort publicly at will and impose their own ideas on learners that it is the habitual usage of foreigners. No matter what reason it is, it is incorrect to instruct grammar like that. It is, actually, a desecration of grammar, a presentation of utter irresponsibility. Traditional grammar is just to tell learners what is what and learners are required to do as they are required. It is so prescriptive, arbitrary and rough that even learner can recite some rigid grammatical rules and collect some dead sentences for a while, they still get nowhere for misunderstanding the connotation of the very rules.

As contrast to traditional grammar is the "revolutionary" human approach to grammar, scholastic grammar. Louis Hjelmslev once affirms that language is no external accompaniment but it lies deep in the mind of man, a wealth of memories inherited by the individual and the tribe. So inextricably has language grown in side personality, home, nation, mankind and the life itself that it may be asked whether language is a mere reflection. The same is true of grammar itself. Grammar also can be considered as a distinctive mark of home and nation and nation's patent of nobility. Essentially, grammar was to contribute to a characterization of a nation, conceived as a super-individual social institution. For this reason, scholastic grammar rooted deeply in human society can explain the fluctuating and changing phenomenon while traditional grammar, a disconnected, external facet of grammar itself can not do.

Here is a case in point, the sentence in a noted poem To His Coy Mistress (1650) written by Andrew Marwell.

“...I would

Love you ten years before the Flood,

And you should, if you please, refuse

Till the conversion of the Jews"

The modal verb shall can be used in sentences only when the subject is $I$ or we in traditional grammar. However it is absolutely true in scholastic grammar. It seems that a male lover uses exaggerated metaphors to appeal to his 
female beloved. In fact, this sentence, on the other hand, can be paraphrased with implied meaning "This is my order and you must listen to me." What a kind of male's law! It is not difficult to see that grammar is intrinsically interwoven with man's thought and feelings, mood, aspiration and will. This is a good example of scholastic grammar. So in college English teaching activities, it is cursory to draw a conclusion that such combinations are incorrect. Similarly, a wool and creations are on the same ground. Take the post-position of the adjective for example; the following exposition is intended to pass in review the principal influences.

1) The tendency to continue the practice prevailing in French, which, save for certain cases, has the adjective after the noun, make itself felt in the post- position of a good many, mostly Romantic adjective, in certain combinations belonging chiefly to the language of civil or ecclesiastical law or of politics.

2) Separate mention may be made of the still frequent post-position of the attributive adjective in the language of heraldry.

3) The influence of Latin grammars makes itself felt in the post-position of the adjective in certain grammatical terms, thus regularly nominative absolute, ablative absolute.

4) In certain combinations post-position is sometimes practiced because they are somehow associated with certain phrases lingering in the speaker's or writer's mind, in which the adjective stands traditionally after the noun.

5) It is also in verse that post-position of the adjective is often necessitated by the requirements of metre or rhythm.

Then, what effect can be achieved by using such unusual arrangement?

The fact that the placing of a word(-group) in an unusual position makes for emphasis, often causes an adjective to be put after its head-word, post-position not seldom adding to the intended solemnity of the utterance. And, to secure, distinctness or emphasis, and also for stylistic effect, two or more adjective modifiers of a noun are not seldom placed after the latter. The force which may lie in post-position of a number of adjectives enhances the beauty and impressiveness of composition. It proves that it is not difficult to find a satisfactory answer in scholastic grammar while these reasons and effects above can never be found in traditional grammar. Another example, in many cases the rule, "the attributive adjective which modifies the indefinite pronoun should be placed after the indefinite pronoun", is fixed in traditional grammar. It may be asked: is there any contradiction between what is said in traditional grammar and what has just been asserted here? A puzzle, at least in part, lingered in learner's mind and problem maybe arises. How can English language learner use what has not been perceived appropriately for him?

While in scholastic grammar, there are many explicitly detailed information presented for learner. H. Poutsma, an outstanding representative of scholastic grammar, explained that the utter semantic insignificance of the noun modified as compared with that of the modifying adjective may, at least in part, be responsible for the post-position of the latter in combinations with thing and especially things. A further and, perhaps, more potent factor operating towards the same effect, may lie in the semantic analogy of these combinations with such as consisting of anything (something, nothing, or everything) with an adjective as in anything useful, etc., in which the adjective is felt as an undeveloped clause. Thus anything useful can be comprehended as anything that is useful. It is also consistent with the two important grammar principles: end-focus and end-weight proposed by Leech et al. (1985) in The Comprehensive Grammar of English Language. The two principles require that words or phrases with new information should be placed last accordingly. It is quite clear that the following two sentences

A) The wind ruined the crops last night.

B) The crops were ruined by the wind last night.

have the same meaning in the traditional grammar. A single line between them is that sentence A) is in active voice and sentence B) is in passive one. However, there are many differences between them in scholastic grammar. Besides the active and passive voice, there are more important things here. The fresh information in sentence A) is the crops while the wind in sentence B) respectively, which results in different illocutionary points i.e., what was ruined last night? and what ruined the crops last night? In other words, the fresh information imparted to the two sentences is distinctive enough to differentiate the intended meaning of the speaker. In addition, the relatively superior importance and consequent emphasis are quite different when the two are contrasted. Therefore, sentence A) and B), actually, are not the same. Just as a famous saying goes "Only what has been understood can be called real knowledge and such real knowledge can be used appropriately". Then only through understanding the scholastic grammar rooted in culture of society can English language learner in 
college get a better appreciation of language, inseparable from man and follow him in all his works. And this is also accordant with college students' interests and hobbies psychologically.

Furthermore, Immanuel Kant, a great philosopher and thinker in German, once divided the process of cognition of human being into three stages: perception, understanding and reasoning. Obviously, the majority of the college students are above the first stage. Young people tend to be curious about not only the result what but also the process how and the reason why. They dislike being ordered to follow something which they absolutely do not know. Naturally, English grammar is not an exception for them. Scholastic grammar is, therefore, much more sufficient than traditional grammar in the process of language learning.

In addition, along with the rapid development of science and technology, great changes have taken place in the world. Everything is changing quickly, so is grammar. Grammar does not mean a static concept or a series of rules but means something more pliable; it is, as it were, animate or articulated as human being.

\section{Conclusion}

From the arguments above, scholastic grammar should be considered as a key position in college English teaching. Whichever teaching methods, as mentioned previously, grammar-translation method or audio-visual and audio-lingual or communicative approach are employed, scholastic grammar with sufficient preparation has won much approval. This is not said to minimize the value of all these grammatical rules in traditional grammar and all these efforts, but to point out the danger: the danger that in our zealous haste towards the goal of get a better score in examinations we may overlook grammar itself.

Teaching grammar does not simply mean teaching students to master the grammatical structure which is a commonplace in traditional grammar; moreover, it provides a key to the cognitive system of a nation. Departed from human culture, pure grammar does not exist in life. Those so-called grammarians often seem to be studying grammar and language teachers are assumed to teach learners grammar but that is an illusion actually.

In the process of language learning, learners have to be able to produce and understand contextually appropriate sentences. Of course, they cannot avoid grammar. Yet, the present condition in language teaching and learning is far from the grammar itself. What is required, in the long run, is to reconsider the position of grammar and establish a real and rational attitude towards grammar. Rather than to conclude on an entirely positive note, a strong caution needs to be exercised here. In consequence, it is quite clear and uncontroversial to say that more attention, for one thing, should be paid to scholastic grammar in the future, as it is much more fundamental than traditional grammar in modern classroom and, for another, aimed at the real knowledge that teacher delivered, learning that goes on within apprenticeships coaching, repeated practice is far less enough for effective classroom instruction. Correspondingly, the effective treatment of grammar should be consciously applied in actual language teaching. It should be treated as aids and resources not only of function that speaker intends to assign to his utterance but also of meaning that aims to serve the understanding of people in linguistic context and in social context, which is significant to both language learning and teaching.

\section{Acknowledgements}

I would like to take this opportunity to thank all those who have given much help to me. First and foremost, sincere thanks and gratitude to Yonglin Fu who deserves a great deal of thanks for his help and encouragement. Appreciation is also expressed to Weimin Wang for always being kind, understanding, and helpful during the undertaking of the work. Their tremendously thorough and timely feedback allowed me to move through this process with confidence and poise. I can only hope to have a career as successful and lucrative as theirs and to offer future students mentorship and guidance as they have to me. Finally, I owe a lot to my family for their constant support and love.

\section{References}

Alexander, L. G. (1988). Longman English grammar. Harlow: Longman.

Bolinger, D. (1981). Sears. Aspects of language. New York: Harcourt Brace Jovanovich.

Du, X. H. (2013). English Grammar Automatic Output Model under Non-native Environment. Theory and Practice in Language Studies, 3(1), 29-34. https://doi.org/10.4304/tpls.3.1.29-34

Du, X. H. (2017). A Study of Multidimensional Teaching Model of College English Grammar Based on MOOC. Language Education.

Ferdinand de Saussure. (1959). Course in general linguistics. New York: Philosophical library.

Harmer, J. (1983). The practice of English language teaching. London: Longman. 
Henry, B. (1957). The making of English. Macmillan and Company Limited.

Hjelmslev, L. (1953). Prolegomena to a theory of language. Baltimore: Warerly Press, Inc.

Jesperson, O. (1924). The philosophy of grammar. London: George Allen \& Unwin LTD.

Krashen, S. (1981). Second language acquisition and second language learning. Oxford: Pergamon.

Krashen, S. (1988). The Input Hypothesis: Issues and Implications. London: Longman.

Langacker, R. (2013). Essentials of cognitive grammar. Oxford: Oxford University Press.

Littlewood, W. (1984). Foreign and Second Language Learning. Great Britain: Cambridge University Press.

Marvell, A. (1650). To His Coy Mistress. Northampton: MA, Gehenna Press.

Poutsma, H. (1928). A Grammar of Late Modern English. Groningen: P. Noordhoff.

Quirk, R. (1972). A Grammar of Contemporary English. London: Longman Group Limited.

Terrell, T. (1991). The Role of Grammar Instruction in a Communicative Approach. Modern Language Journal, 75, 52-63. https://doi.org/10.1111/j.1540-4781.1991.tb01083.x

VanPatten, B. (1996). Input Processing and Grammar Instruction in Second Language Acquisition. Norwood. New Jersey: Ablex.

Weidong, D., \& Xianju, Y. (2005). Teaching Mode for Second Language Acquisition. English World, (2), 2-8.

Xia, Z. H. (2004). The effectiveness of different grammar instructions. CELEA, (1), 23-28.

\section{Copyrights}

Copyright for this article is retained by the author(s), with first publication rights granted to the journal.

This is an open-access article distributed under the terms and conditions of the Creative Commons Attribution license (http://creativecommons.org/licenses/by/4.0/). 